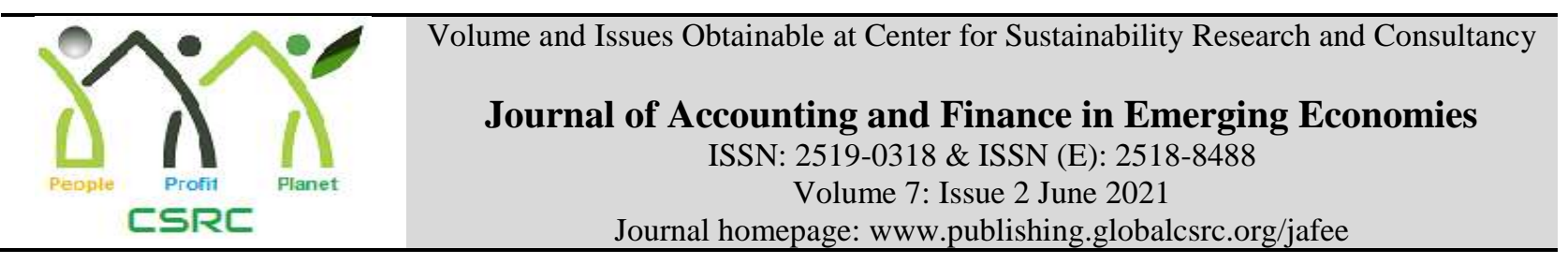

\title{
Capital Flow, Capital Control, and Economic Growth: Evidence from Developed \& Developing Economies
}

*Lubna Khan, Iqra University, Karachi, Pakistan

Imtiaz Arif, Iqra University, Karachi, Pakistan

Syed Ali Raza, Iqra University, Karachi, Pakistan

*Corresponding author's email: lubnakhan922@gmail.com

ARTICLE DETAILS
History
Revised format: May 2021
Available Online: Jun 2021

Keywords

FDI, Remittances, External

Debt, Exports, Capital

Control, and Economic

Growth.

JEL Classification

O11 F15 P45 F63 F66

\section{ABSTRACT}

Purpose: The current paper analyzes the effects of capital flow and capital control on economic growth in developed and developing countries. We used four main components of capital flow such as, FDI, exports, remittances and external debt

Design/Methodology/Approach: The econometric models are tested by using the annual data of 1995-2017 from 54 countries, classified as developed (high-income) and developing (middleincome) economies.

Findings: Empirical estimation of PMG revealed that all four components of capital flow augment the economic growth in both developed and developing countries. However, restrictions on these flows reduces the impact of FDI, external debt and exports but raises the influence of remittances on the economic growth. Implications/Originality/Value: The findings of this paper also provides some useful insights for policymakers to use capital control as a tool for economic progress.

(C) 2021, The authors, under a Creative Commons AttributionNonCommercial 4.0

Recommended citation: Khan, L., Arif, I. and Raza, S. A. (2021). Capital Flow, Capital Control and Economic Growth: Evidence from Developed \& Developing Countries. Journal of Accounting and Finance in Emerging Economies, 7 (2), 467-482

\section{Introduction}

Foreign capital flow plays a crucial role in the global economy. It closely ties the countries financial and economic conditions. Country embraces foreign capital to supplement its domestic investment. It is used as a growth catalyst, which raises national income and improves economic performance (Ahmed \& Zlate, 2014). Several past studies suggest that free capital flow across countries not only improves domestic businesses, but also increases labor efficiency and technological advancements (Cleeve, Debrah, Yiheyis, 2015; \& Others). In order to understand the effects of capital flow on global economy, past studies discuss four main drivers of foreign capital that may affect economic activities of the country, which are; foreign direct investment, 
remittances, exports and external debt.

Over the past few decades, foreign direct investment is found one of the key determinants of economic growth. Numerous past studies suggest that FDI influences economy by enlarging labor capabilities, encouraging good governance and bringing technological advancements (Turnbull, Sun \& Anwar, 2016; \& others). Moreover, it also assists local business to perform well by creating competitive learning environment (Debrah et al., 2015 \& Chen and Zulkifli, 2012). According to World Investment Report (2017), global FDI flows across countries are expected to increase by five percent in 2018 up to $\$ 1.85$ trillion, from which $\$ 660$ to $\$ 740$ billion is expected to flow to developing countries. In addition to that, remittances play an essential role in strengthening the financial condition of economy. It perceives as a major source of funding for the developing countries. Several studies identified that remittances improves literacy rate and reduces poverty in the host countries (see for example, Jawaid and Raza, 2012 \& Mohapatra, 2011). Migration and Development report (2016) revealed 0.4 percent increase in remittances to developing countries, amounted as \$431.6 billion in 2015.

Another important driver of international capital flow is exports. It is viewed as an economic engine, because it effects country's balance of payments, employment and ultimately growth. By increasing productivity, exports help local firms to grow. Previous researches corroborate that exports increases the local business efficiency by introducing them in to the global market (Dritsaki, 2013 \& Kim et al., 2011). Furthermore, external debt is also an important factor of foreign capital that assumes as a source of funding as well as liability. State borrows money from another state to fix their financial issues. From the past literature, it is found that external debt has a mixed relationship with economic growth. If the money is borrowed for development purpose, it is favorable, otherwise, gives deleterious effect on the economy (Delong \& Summers; Ajayi \& Oke, 2012, among others).

Despite the increasing trend of capital flow across countries, the relationship between capital flow and economic growth is highly controversial. More specifically, in the wake of global financial crisis (2008-2009), an excess amount of capital flown from developed markets to emerging markets that drives attention of several researchers and policymakers towards this subject. Excess flow of capital across boundaries seriously distort the economies by creating asset price bubbles. It is recently noted that countries (especially developed) started imposing restrictions on the capital inflows (capital control) in the aftermath of the financial crisis in order to safeguard their economies from destabilization and currency appreciation. Thus, this current study is highly motivated by the surge and sudden stop of capital flow across countries. Though, numerous studies have been conducted in this area but rather focused on the determinants that attract capital flow in the country (De Vita and Kyaw, 2008; Fedderke and Liu 2002; \& many others) or studies which are more focused on the individual analysis of capital flow and economic growth (Iamsiraroj and Ulubaşoğlu, 2015; Ali and Mustafa; 2012; Jouini, 2015; Almfraji \& Almsafir; 2013, among others). However, the current study tries to investigate the effect of four main components (FDI, remittances, exports \& external debt) of capital flow on the economic growth and also studies the same relationship in the presence of capital control, specifically in the advanced and emerging countries. We have used high-income and middleincome level regions, because as per the aforementioned statistics, vast amount of capital flow noted across these regions.

The rest of the paper is organized in the following manner: Section II highlights the theoretical background and empirical evidences. Section III explains the methodology of the study. Section 
IV reveals the empirical results and discussion, and finally, section V summarizes the concluding remarks and policy implications.

\section{Related Literature}

Economic theory states that free flow of capital across countries carries several mutual benefits; it raises productivity, leads to effective use of resources and ultimately boosts economy. However, the large and volatile flow of capital sometimes harm the economic system. Due to which, this complex relationship of capital flow, capital control, and economic growth have derived great attention of several researchers and policymakers in both developed and developing nations. In the present paper, we have used four components of capital flow comprises FDI, external debt, remittances, and exports. Theoretically, capital flow can contribute to the economy in several ways. Neoclassical theory depicts that foreign inflow raises capital stock and hence foster economic growth by funding investments (Solow, 1956). Additionally, the new growth theory claims that foreign flow is more useful than local investment because it brings technological advancements that reduce negative returns on investments and lead to longrun economic development. According to endogenous growth theory, capital flow benefits the economy in two ways, directly by high investments and technological improvement and indirectly by human development, quality institutions, and good infrastructures.

In the empirical literature, several studies have supported the positive linkage between foreign direct investment and economic growth (Iamsiraroj and Ulubaşoğlu, 2015; Sbia, Shahbaz, and Hamdi, 2014; Omri, Ngugen and Rault, 2014; Antwi, Mills, Mills and Zhao, 2013; Tekin, 2012; among many more). It is also found that FDI not only good for the economy, but it also improves human development, domestic firm performances, innovations and labor force (Yiheyis, Debrah, and Cleeve, 2015 \& Ahmed, 2012). Conversely, Saini, Baharumshah, and law (2010) stated that independent economic policies influence FDI and found the inverse relationship between FDI and economic growth in their study. Temiz and Gokmen (2013) study resulted that FDI inflow and gross domestic product have not correlated to each other due to some insignificant investment. On the other hand, very few authors have studied the effect of capital control in the context of FDI and stated that restriction on a direct investment reduces the flow of FDI in the economy, which subsequently detriments the economic system (Elo, 2007 \& Asiedu, 2004).

In addition to the above, external debt plays a key role in the development of the economy, financing domestic projects that lead to economic progress. By reviewing past literature, it is identified that external debt and economic growth both have a mixed relationship; it considers good in the short-run but deleterious in the long-run. Voluminous studies have been published on the nexus between external debt and economic growth (Malik, Hayat, and Hayat, 2010; Kumar and Woo, 2010; Johansson, 2010; Fosu, 2007 and many more). Ali and Mustafa (2012) declared that higher international borrowing carries serious troubles for the economy. Contrary, Daud, Azman-Saini, and Ahmad (2013) found a positive association between external debt and economic growth, by reforming and diversifying debt policies, external debt can remarkably contribute to the economic growth.

Extensive literature illustrates the positive contribution of remittances in the economic growth of the country (Jouini, 2015; Kumar, 2013, Jawaid and Raza, 2012, Fayissa and Nsiah, 2008, etc). Nyamongo, Misati, Kipyegon, and Ndirangu (2012) cited that the flow of remittances through legitimate channels can lead to financial development. Free flow of remittances reduces the need for international aid and increase the probability of investments (Anzoategui, Kunt and Peria, 2014 \& Ambrosius, and Cuecuecha, 2013). Adams and Cuecuecha (2013) explicated that 
remittances play an integral role in alleviating poverty and boosting investment. Hatmi and Uddin (2013) reported that remittances and poverty both are interlinked with each other. In addition, a study investigates worker's behavior towards remittances; it is found that most people send their money back home in order to fulfill educational purposes (Arcangelis et al., 2015). Contrary to the above literature, Abdih, Chami, Dagher, and Montiel (2015) declared remittances inflow as a curse for the country, according to them, remittances deteriorate the quality of institutions.

Furthermore, several past studies have also been extensively discussed exports as a crucial determinant of economic growth. As Medina- Smith (2001) mentioned that exports are one of those determinants that accelerate economic growth. It raises productivity and enhances competition among domestic businesses. According to a trade theory, exports can strengthen the economic system through different channels. There are two groups of literature, one supports the relationship and the other opposed. In the first group, Dritsaki (2013) found bidirectional causality between exports and economic growth and stated that both exports and economic growth are important for each other. More investment opportunities in exports sector act as a catalyst for economic development (Stiakakis \& Dritsaki, 2014). Empirical evidence shows that physical infrastructure enhances exports and subsequently spurs growth (Portugal-Perez \& Wilson, 2012). Schneider (2005) asserted that high-technology increases trade which might lead to economic expansion. On the contrary, in the second group, Gokmenoglu, Sehnaz, and Taspinar (2015) examined that sustainable economic growth attracts exports of the country. On the other hand, in the wake of financial crisis, the debate on the restriction of capital flow has reinvigorated and hence several past studies conducted based on capital control and its effects on the economy (Korinek, 2017; Forbes, Fratzscher, and Straub, 2015, etc.).

\section{Methodology}

The objective of the current study is to empirically analyze the role of capital flow and capital control in economic growth. The basic assumption of economic growth is that the country's national output is determined by its foreign and domestic capital, labor force and other productive factors. In order to explain the theoretical phenomenon of economic growth, we construct the model by using Cobb-Douglas production function;

$$
Y=f(K, L, A) \quad e q-----(1)
$$

Where, $\mathrm{Y}$ is the total output, $\mathrm{K}$ is the domestic and foreign capital, $\mathrm{L}$ is the labor force and $\mathrm{A}$ is the other productive factors. We also follow the endogenous growth theory from the study of Barro (1990) and used some determinants of economic growth The above function can further be specified as follows;

and

$$
L G D P_{i t}=\beta_{0}+\sum_{i=1}^{4} \beta_{i} J_{i t}+\alpha_{j} K_{j t}+e_{t} \quad \quad e q \ldots \text { (2) }
$$

$$
L G D P_{i t}=\beta_{0}+\sum_{i=1}^{4} \beta_{i} J_{i t}+\alpha_{j} K_{j t} * C C+e_{t}
$$

From the above equation $1, \mathrm{LGDP}_{i t}$ is the natural logarithm of gross domestic product, used as a proxy of economic growth. Here, $\mathrm{J}_{i t}$ refers to the control variables used in the study where $i=1$, 2,3,4 and t denotes the number of years. The control variables are labor force, capital formation, and government expenditures and domestic credit in the financial sector named as financial development. In addition, $\mathrm{K}_{j t}$ describes the explanatory variables i.e. capital flow variables, where $j=1,2,3,4$, it comprises of foreign direct investment, external debt, worker's remittances, and exports. However, the description of equation 2 is same as above except one variable, i.e. $\mathrm{K}_{j t}$ * CC. It is the interaction term of capital flow and capital control. Basically, capital control is the restriction on the amount of assets flow into the country. In this study, we developed an interaction term in order to determine the effects of capital flow on economic growth in the 
presence of capital control, and $\mathrm{e}_{t}$ refers to the error term.

\section{Data Source and Estimation Process}

The data series of variables used in the study was extracted from World Bank (World Development Indicators) excluding capital control, which was taken from IMF's Annual Report on Exchange Arrangements and Exchange Restriction (2018) and binary tabulated by Fernández, Klein, Rebucci, Schindler and Uribe (2016). We used annual time series data of 54 countries from the period of 1995-2017. We use the time span till 2017 because there is no data available of capital control after the given time. The selected data set is further comprised of two subsamples, such as, developed and developing countries. Developed countries entail 20 highincome classified economies, whereas, developing countries entail 34 upper and lower-middle income classified economies (Countries list is attached in Appendix). For estimation, we run the model individually for focused variables using pooled Mean group estimation (PMG). Moreover, the same technique was used in the interaction term model. Prior to that, the homogeneity of the was test by cross-section dependendence (CD) test, second-generation Unit root (CIPS test) and latter checked the long-run association between variables using Pedroni Cointegration test.

\section{Empirical Results and Discussion}

\section{Cross-Sectional Dependence and CIPS Unit Root Test}

Before investigating the stationary property of the data series, we check the cross-section dependence among panel. According to Bhattacharya et al. (2016), cross-sectional dependence exists among countries due to geographical and macroeconomic policies (such as, financial crisis, monetary and fiscal policies, trade policies, the great depression, and others), which may have a spillover effect. Therefore, it is better to measure an appropriate homogeneity among variables. Otherwise, the panel unit root gives biased results. To examine the cross-section dependence, we test Pesaran (2004) CD test. As expected, it is confirmed by the rejection of the null hypothesis that the cross-section dependence exists among the panel. Table 1 illustrates the statistics of CD test, which shows the rejection of null hypothesis of all the considered variables at the significance level of $1 \%$.

Table 1: Test for cross-sectional dependence \& CIPS unit root

\begin{tabular}{l|lllllllll}
\hline Variables & $\boldsymbol{G D P}$ & $\boldsymbol{F D I}$ & $\boldsymbol{E D}$ & $\boldsymbol{R E M}$ & $\boldsymbol{E X P}$ & $\boldsymbol{L F}$ & $\boldsymbol{C F}$ & $\boldsymbol{G C}$ & $\boldsymbol{F D}$ \\
\hline \multirow{2}{*}{ Pesaran CD test } & $206.18^{*}$ & $78.03^{*}$ & $17.53^{*}$ & $26.60^{*}$ & 144.79 & $153.09^{*}$ & $125.91^{*}$ & $190.84^{*}$ & $72.75^{*}$ \\
& $*$ & $*$ & $*$ & $*$ & $*$ & $*$ & $*$ & $*$ & $*$ \\
$* \mathrm{P}-$ value & 0.00 & 0.00 & 0.00 & 0.00 & 0.00 & 0.00 & 0.00 & 0.00 & 0.00 \\
\hline \multicolumn{7}{l}{ The unit root test with cross-sectional dependence } \\
\hline $\begin{array}{l}\text { CIPS (Level) } \\
\begin{array}{l}\text { CIPS (first } \\
\text { difference) }\end{array}\end{array}$ & -1.100 & -3.120 & -2.010 & -1.760 & -1.560 & -2.060 & -1.290 & -1.240 & -2.120 \\
\hline
\end{tabular}

$*, * *$ indicates significance level respectively at $1 \%$ and $5 \%$.

Source: Authors' estimation.

The presence of cross-section dependence among panel encourages us to test the stationary property of variables by using second-generation unit root test i.e. CIPS, proposed by Pesaran (2007). We used second generation unit root test because the first-generation unit root has some shortcomings. It gives spurious results with slight distortions especially when it is applied on a dataset that contains cross-sectional dependence (Bhattacharya et al., 2016; Alam, Paramati, Shahbaz and Bhattacharya, 2016; others). The results of CIPS unit root test is shown in table 1, confirm that the variables are non-stationary at level and stationary at first difference. Hence, we conclude that all the variables are integrated at order one i.e. I (1). 


\section{Panel Cointegration}

Stationary property of the data series suggests an expected long-run relationship between variables. In order to confirm the association, we perform Pedroni (Engle-Granger based) panel cointegration for both developed and developing countries. A panel cointegration test is essential because it prevents OLS from spurious results mainly when variables are cointegrated (EngleGranger, 1987). Numerous past studies have also used this approach (instance: Paramati and Alam, 2015; Brahmasrene and Lee; 2013 \& others). Table 2 shows the results of Pedroni cointegration test of each model, respectively and revealed that all the focused and control variables are cointegrated with economic growth at the significance level of 5\%.

Table-2: Results of Pedroni ((Engle-Granger based) Panel Cointegration

\begin{tabular}{|c|c|c|}
\hline Estimates & Stats. & Prob. \\
\hline \multicolumn{3}{|c|}{$G D P=f(L F+K+G C+F D+F D I * C C)$} \\
\hline Panel v-statistic & -0.934 & 0.825 \\
\hline Panel rho-statistic & 6.120 & 1.000 \\
\hline Panel PP statistic & -7.253 & 0.000 \\
\hline Panel ADF statistic & -7.939 & 0.000 \\
\hline \multicolumn{3}{|c|}{ Alternative Hypothesis: Individual AR Coefficient } \\
\hline Group rho-statistic & 9.733 & 1.000 \\
\hline Group PP statistic & -12.722 & 0.000 \\
\hline Group ADF statistic & -11.669 & 0.000 \\
\hline \multicolumn{3}{|c|}{$G D P=f(L F+K+G C+F D+E D * C C)$} \\
\hline Panel v-statistic & -0.883 & 0.811 \\
\hline Panel rho-statistic & 5.093 & 1.000 \\
\hline Panel PP statistic & -5.485 & 0.000 \\
\hline Panel ADF statistic & -6.505 & 0.000 \\
\hline \multicolumn{3}{|c|}{ Alternative Hypothesis: Individual AR Coefficient } \\
\hline Group rho-statistic & 7.649 & 1.000 \\
\hline Group PP statistic & -12.054 & 0.000 \\
\hline Group ADF statistic & -9.524 & 0.000 \\
\hline \multicolumn{3}{|c|}{$G D P=f(L F+K+G C+F D+R E M * C C)$} \\
\hline Panel v-statistic & -0.856 & 0.804 \\
\hline Panel rho-statistic & 6.486 & 1.000 \\
\hline Panel PP statistic & -8.128 & 0.000 \\
\hline Panel ADF statistic & -9.307 & 0.000 \\
\hline \multicolumn{3}{|c|}{ Alternative Hypothesis: Individual AR Coefficient } \\
\hline Group rho-statistic & 10.470 & 1.000 \\
\hline Group PP statistic & -11.701 & 0.000 \\
\hline Group ADF statistic & -11.427 & 0.000 \\
\hline \multicolumn{3}{|c|}{$G D P=f(L F+K+G C+F D+E X P * C C)$} \\
\hline Panel v-statistic & -1.393 & 0.918 \\
\hline Panel rho-statistic & 6.074 & 1.000 \\
\hline Panel PP statistic & -6.741 & 0.000 \\
\hline Panel ADF statistic & -7.568 & 0.000 \\
\hline
\end{tabular}




\begin{tabular}{lll}
\hline Alternative Hypothesis: Individual AR Coefficient & & \\
\hline Group rho-statistic & 9.643 & 1.000 \\
Group PP statistic & -13.210 & 0.000 \\
Group ADF statistic & -10.069 & 0.000 \\
\hline
\end{tabular}

The null hypothesis of Pedroni's (1997) panel cointegration procedure is no cointegration Source: Authors' estimation.

\begin{tabular}{|l|lll|lll|lll|}
\hline Variables & Model I & & & Model II & & \multicolumn{3}{|l|}{ Model III } \\
\hline GDP & Coef. & t-stats & Prob. & Coef. & t-stats & Prob. & Coef. & t-stats & Prob. \\
\hline LF & -0.003 & -0.040 & 0.971 & 0.569 & 8.410 & 0.000 & -0.004 & -0.080 & 0.935 \\
K & 0.290 & 12.770 & 0.000 & 0.035 & 1.890 & 0.059 & 0.182 & 14.510 & 0.000 \\
FD & 0.566 & 9.800 & 0.000 & 0.012 & 2.780 & 0.005 & -0.083 & -6.410 & 0.000 \\
GC & -0.166 & -6.850 & 0.000 & 0.389 & 12.280 & 0.000 & 0.375 & 16.830 & 0.000 \\
FDI & 0.019 & 5.670 & 0.000 & - & - & - & - & - & - \\
ED & - & - & - & - & - & - & - & - & - \\
REM & - & - & - & 0.039 & 7.710 & 0.000 & - & - & - \\
EXP & - & - & - & - & - & - & 0.083 & 11.430 & 0.000 \\
\hline
\end{tabular}

\section{Pooled Mean Group Estimation}

We proceed further to estimate the econometric models by using pooled mean group (PMG) estimator. PMG estimator is a useful approach, proposed by Pesaran et al. (1999). It allows heterogeneity in the short-run, while restricting coefficient to be same in the long run across countries. Contrary to the conventional techniques, such as, fixed and random effect models, where all slopes and intercepts are same across panel. PMG provides consistent and efficient results when the panel contains homogeneity. Therefore, for this study, PMG is considered the most appropriate approach. To report PMG estimations, we perform Hausman test under the null hypothesis of PMG results efficiency against MG results efficiency. The statistics of the Hausman test accept the null hypothesis. Thus, we conclude that PMG estimations are consistent and efficient for estimating the studied models.

In this study, we categorized our panel data into two income level regions, i.e. high income and middle-income. Under the middle income, upper middle and lower-middle-income level countries are combined. However, the low-income countries are not selected due to the unavailability of data. Table 3, 4, 5 and 6 present the long run PMG estimations from high and middle-income countries, respectively.

Table 3 illustrates the long run coefficients of high-income countries, which shows that the flow of foreign direct investment in high-income countries significantly contributes to the economy. Whereas, the finding supports the notion that remittances are an important element of economic growth. It is also evident that exports boost the national output of developed countries. 


\begin{tabular}{|l|l|l|l|}
\hline $\begin{array}{l}\text { Hausman test } \\
\text { Statistics }\end{array}$ & $\mathrm{H}=0.45 . \mathrm{p}$-value $=0.998$ & $\mathrm{H}=1.13, \mathrm{p}$-value $=0.980$ & $\mathrm{H}=0.50, \mathrm{p}$-value $=0.997$ \\
\hline
\end{tabular}

Notes: There is only one country of higher income class of external debt, therefore, the external debt model has been removed from the high-income countries.

Source: Authors' estimation.

Table 4 highlights the relationship of capital flow with economic growth in the presence of capital control. The statistics prove that the restriction on foreign direct investment inversely affects the economy. While limited remittances positively contribute to the economic growth. This indicates that money transfer through unfair channels raises corruption, therefore, restricted remittances through proper channels can only increase the national income of the country. Conversely, restrictions on exports negatively affect the economic growth. Exports are considered one of the important determinants of economic growth; specifically in developed countries, exports contribute the largest proportion of the economy.

Table 4: PMG Estimates for Higher Income Countries (Interaction with Capital Control)

\begin{tabular}{|c|c|c|c|c|c|c|c|c|c|}
\hline & \multicolumn{3}{|c|}{ Model I } & \multicolumn{3}{|c|}{ Model II } & \multicolumn{3}{|c|}{ Model III } \\
\hline GDP & Coef. & t-stats & Prob. & Coef. & t-stats & Prob. & Coef. & t-stats & Prob. \\
\hline $\mathrm{LF}$ & -0.267 & $\begin{array}{l}-2.640 \\
10.75\end{array}$ & 0.008 & 1.291 & 6.440 & 0.000 & 0.142 & 2.560 & 0.010 \\
\hline K & 0.315 & $\begin{array}{l}0 \\
12.02\end{array}$ & 0.000 & $\begin{array}{l}0.209 \\
-\end{array}$ & 7.680 & 0.000 & $\begin{array}{l}0.134 \\
-\end{array}$ & $\begin{array}{l}27.590 \\
-\end{array}$ & 0.000 \\
\hline FD & 0.661 & 0 & 0.000 & 0.014 & -1.280 & 0.202 & 0.162 & 20.270 & 0.000 \\
\hline GC & -0.200 & -6.910 & 0.000 & 0.715 & 16.290 & 0.000 & 0.691 & 48.630 & 0.000 \\
\hline $\mathrm{FDI}^{*} \mathrm{CC}$ & -0.002 & -1.250 & 0.211 & - & - & - & - & - & - \\
\hline $\mathrm{ED}^{*} \mathrm{CC}$ & - & - & - & - & - & - & - & - & - \\
\hline $\mathrm{REM}^{*} \mathrm{CC}$ & - & - & - & 0.007 & 3.590 & 0.000 & - & - & - \\
\hline $\mathrm{EXP} * \mathrm{CC}$ & - & - & - & - & - & - & 0.007 & -5.510 & 0.000 \\
\hline $\begin{array}{l}\text { Hausman } \\
\text { Test } \\
\text { Statistics }\end{array}$ & $\mathrm{H}=1.67$ & alue $=0.9$ & & $\mathrm{H}=5.2$ & p-valu & $=0.514$ & $\mathrm{H}=0.5$ & , p-value & $=0.997$ \\
\hline
\end{tabular}

Notes: There is only one country of higher income class of external debt, therefore, the external debt model has been removed from the high-income countries.

Source: Authors' estimation.

The PMG estimations for middle-income countries are reported in Table 5 and 6. In Table 5, it is noticed that free flow of foreign investment across borders significantly increases economic growth of the developing countries. It is because foreign direct investment brings technology, expertise, investment and many other productive things, which ultimately benefit the economy. The coefficients of external debt also prove that the increase in external debt will increase the economic progress. External debt plays an important role in the economy, if it is used for the development purpose. The positive and significant findings of exports confirmed that it is an important determinant of economic growth. However, the relationship between growth and remittances turns significantly negative in middle-income regions. It might be due to the reason that remittance-receiving households usually spend the remitted amount on the consumption rather than investments. 


\begin{tabular}{|c|c|c|c|c|c|c|c|c|c|c|c|c|}
\hline & \multicolumn{3}{|c|}{ Model I } & \multicolumn{3}{|c|}{ Model II } & \multicolumn{3}{|c|}{ Model III } & \multicolumn{3}{|c|}{ Model IV } \\
\hline$G D P$ & Coef. & t-stats & Prob. & Coef. & t-stats & Prob. & Coef. & t-stats & Prob. & Coef. & t-stats & Prob. \\
\hline $\mathrm{LF}$ & -0.312 & -6.390 & 0.000 & 6.063 & 23.254 & 0.000 & 0.012 & 0.220 & 0.825 & 0.294 & 6.270 & 0.000 \\
\hline $\mathrm{K}$ & 0.362 & 15.640 & 0.000 & 0.028 & 5.991 & 0.000 & 0.514 & 22.600 & 0.000 & 0.350 & 17.490 & 0.000 \\
\hline FD & -0.051 & -3.860 & 0.000 & 0.004 & 3.413 & 0.000 & -0.141 & -9.330 & 0.000 & -0.060 & -5.780 & 0.000 \\
\hline GC & 0.545 & 22.660 & 0.000 & -0.098 & -6.968 & 0.000 & 0.400 & 12.890 & 0.000 & 0.303 & 12.350 & 0.000 \\
\hline FDI & 0.014 & 5.500 & 0.000 & - & - & - & - & - & - & - & - & - \\
\hline ED & - & - & - & 0.093 & 2.799 & 0.005 & - & - & - & - & - & - \\
\hline REM & - & - & - & - & - & - & -0.006 & -2.210 & 0.027 & - & - & - \\
\hline EXP & - & - & - & - & - & - & - & - & - & 0.066 & 5.720 & 0.000 \\
\hline $\begin{array}{l}\text { Hausman } \\
\text { Test } \\
\text { Statistics }\end{array}$ & \multicolumn{3}{|c|}{$\mathrm{H}=2.25, \mathrm{p}$-value $=0.894$} & \multicolumn{3}{|c|}{$\mathrm{H}=3.82, \mathrm{p}$-value $=0.7013$} & \multicolumn{3}{|c|}{$\mathrm{H}=2.77, \mathrm{p}$-value $=0.837$} & \multicolumn{3}{|c|}{$\mathrm{H}=1.37, \mathrm{p}$-value $=0.967$} \\
\hline
\end{tabular}

Table 6 illustrates the results of middle-income countries with the interaction term of capital control. We noted that the imposition of capital control on foreign direct investment inversely affects economic growth in middle-income countries. Whereas, restriction on foreign debt remains positive but insignificant with economic growth. The impact of remittances on economic growth remains the same even after imposing the restriction. However, the influence of limited exports turns negative on economic growth in the developing countries.

Table 6 PMG Estimates for Middle-Income Countries (Interaction with

Capital Control)

\begin{tabular}{|c|c|c|c|c|c|c|c|c|c|c|c|c|}
\hline \multirow[b]{2}{*}{ GDP } & \multicolumn{3}{|c|}{ Model I } & \multicolumn{3}{|c|}{ Model II } & \multicolumn{3}{|c|}{ Model III } & \multicolumn{3}{|c|}{ Model IV } \\
\hline & Coef. & t-stats & Prob. & Coef. & t-stats & Prob. & Coef. & t-stats & Prob. & Coef. & t-stats & Prob. \\
\hline LF & 0.328 & 7.950 & 0.000 & $\overline{0} 065$ & -1.390 & 0.164 & 0.238 & 6.100 & 0.000 & 0.271 & 6.880 & 0.000 \\
\hline K & 0.378 & 23.320 & 0.000 & 0.522 & 22.450 & 0.000 & 0.396 & 25.130 & 0.000 & 0.389 & 24.960 & 0.000 \\
\hline FD & -0.086 & -7.860 & 0.000 & 0.136 & -9.600 & 0.000 & -0.051 & -4.570 & 0.000 & -0.063 & -5.600 & 0.000 \\
\hline GC & 0.371 & 13.820 & 0.000 & 0.415 & 15.580 & 0.000 & 0.358 & 13.170 & 0.000 & 0.351 & 13.340 & 0.000 \\
\hline $\mathrm{FDI} * \mathrm{CC}$ & -0.003 & -2.660 & 0.008 & - & - & - & - & - & - & - & - & - \\
\hline $\mathrm{ED} * \mathrm{CC}$ & - & - & - & 0.002 & 1.590 & 0.112 & - & - & - & - & - & - \\
\hline $\mathrm{REM}^{*} \mathrm{CC}$ & - & - & - & - & - & - & -0.008 & -3.920 & 0.000 & - & - & - \\
\hline $\mathrm{EXP} * \mathrm{CC}$ & - & - & - & - & - & - & - & - & - & -0.005 & -2.850 & 0.004 \\
\hline $\begin{array}{l}\text { Hausman } \\
\text { Test Statistics }\end{array}$ & \multicolumn{3}{|c|}{$\mathrm{H}=2.38, \mathrm{p}$-value $=0.912$} & \multicolumn{3}{|c|}{$\mathrm{H}=3.51, \mathrm{p}$-value $=0.742$} & \multicolumn{3}{|c|}{$\mathrm{H}=0.66, \mathrm{p}-$ value $=0.995$} & \multicolumn{3}{|c|}{$\mathrm{H}=0.60, \mathrm{p}$-value $=0.996$} \\
\hline
\end{tabular}

Source: Authors' estimation.

\section{Heterogeneous Panel Non-Causality Test:}

To test the bivariate causality, we used heterogeneous panel non-causality test proposed by Dumitrescu and Hurlin (2012). A simple approach assumes heterogeneous coefficients across all cross-sections. This test requires data series of all the variables to be stationary, we, therefore, use the first and the second difference of the series. The null hypothesis of no causality is tested against the alternate hypothesis of causality among all the cross-sections. If the null hypothesis of homogeneous non-causality is rejected, then we can conclude that a causal relationship exists among the variables. 
Table 7: Heterogeneous Non-Causality for higher Income Countries

\begin{tabular}{lllll}
\hline & W-Stat. & Zbar-Stat. & Prob. & Lag \\
\hline LFDI does not homogeneously cause LGDP & 1.390 & 0.759 & 0.001 & 2 \\
LGDP does not homogeneously cause LFDI & 3.524 & 7.616 & 0.000 & 2 \\
LREM does not homogeneously cause LGDP & 2.257 & 3.335 & 0.001 & 1 \\
LGDP does not homogeneously cause LREM & 3.202 & 6.194 & 0.000 & 1 \\
LEXPS does not homogeneously cause LGDP & 3.745 & 7.836 & 0.000 & 1 \\
LGDP does not homogeneously cause LEXPS & 2.797 & 4.969 & 0.000 & 1 \\
\hline LFDILCC does not homogeneously cause LGDP & 1.584 & 1.381 & 0.068 & 2 \\
LGDP does not homogeneously cause LFDILCC & 2.413 & 4.047 & 0.000 & 2 \\
LREMLCC does not homogeneously cause LGDP & 1.555 & 1.214 & 0.225 & 1 \\
LGDP does not homogeneously cause LREMLCC & 2.639 & 4.492 & 0.000 & 1 \\
LEXPSLCC does not homogeneously cause LGDP & 1.625 & 1.426 & 0.154 & 1 \\
LGDP does not homogeneously cause LEXPSLCC & 1.830 & 2.045 & 0.041 & 1 \\
\hline
\end{tabular}

Source: Authors' estimation.

The results of the panel non-causality test are reported in Table 7 and 8 for high and middleincome regions, respectively. The findings of Table 7 established a bidirectional causal relationship between foreign direct investment, exports, and remittances with the gross domestic product in high-income countries. However, a bidirectional causality is also noticed among foreign investment and GDP in the presence of a capital control. Whereas, a unidirectional causal relationship observed among GDP to controlled remittances and GDP to controlled exports in developed countries. On the other side, Table 8 illustrates the results of panel non-causality for middle-income countries. We noted that all the variables have a bidirectional relationship with the gross domestic product. Similarly, the restricted capital flows also have a bidirectional causal relationship with GDP in the middle-income level nations.

Table 8: Heterogeneous Non-Causality for Middle-Income Countries

\begin{tabular}{|c|c|c|c|c|}
\hline & W-Stat. & $\begin{array}{l}\text { Zba0072 } \\
\text { Stat. }\end{array}$ & Prob. & Lag \\
\hline LFDI does not homogeneously cause LGDP & 1.882 & 2.428 & 0.015 & 1 \\
\hline LGDP does not homogeneously cause LFDI & 4.293 & 10.484 & 0.000 & 1 \\
\hline LED does not homogeneously cause LGDP & 2.465 & 4.273 & 0.000 & 1 \\
\hline LGDP does not homogeneously cause LED & 3.299 & 6.991 & 0.000 & 1 \\
\hline LREM does not homogeneously cause LGDP & 2.625 & 4.863 & 0.000 & 1 \\
\hline LGDP does not homogeneously cause LREM & 3.991 & 9.373 & 0.000 & 1 \\
\hline LEXPS does not homogeneously cause LGDP & 1.947 & 2.621 & 0.009 & 1 \\
\hline LGDP does not homogeneously cause LEXPS & 4.345 & 10.544 & 0.000 & 1 \\
\hline LFDILCC does not homogeneously cause LGDP & 1.699 & 1.815 & 0.070 & 1 \\
\hline LGDP does not homogeneously cause LFDILCC & 4.361 & 10.710 & 0.000 & 1 \\
\hline LEDLCC does not homogeneously cause LGDP & 2.262 & 3.612 & 0.000 & 1 \\
\hline LGDP does not homogeneously cause LEDLCC & 3.236 & 6.786 & 0.000 & 1 \\
\hline LREMLCC does not homogeneously cause LGDP & 1.884 & 2.411 & 0.016 & 1 \\
\hline LGDP does not homogeneously cause LREMLCC & 4.640 & 11.518 & 0.000 & 1 \\
\hline LEXPSLCC does not homogeneously cause LGDP & 1.868 & 2.360 & 0.018 & 1 \\
\hline LGDP does not homogeneously cause LEXPSLCC & 5.495 & 14.345 & 0.000 & 1 \\
\hline
\end{tabular}

Source: Authors' estimation.

\section{Conclusion}

After the liberalization policies, capital is allowed to flow freely around the globe. But, simultaneously create several problems for the countries. Capital control policies have been introduced by many countries to prevent their economies from disaster. Therefore, in the current 
study, we aimed to investigate the effect of capital flow and capital control on economic growth in high and middle-income regions. We selected four types of capital flows that highly contribute to economy, they are FDI, exports, remittances and external debt. Before estimating models, we assessed cross-section dependence, integration property and the long-run relationship of the variables. Empirical results showed that all four components of capital flow have a positive and significant impact on the economic growth. Similarly, the interaction term of remittances, exports and external debt also revealed positive and significant impact on economic growth except for foreign direct investment, which shows a negative effect. That means, the restricted capital flow not only boost the economy but also safeguard it from creating asset bubbles and price boom. However, the restricted flow of direct investment in the country reduces the pace of economic growth. In addition, this study also investigates the positive association of labor force, capital and government consumption with economic growth. Similar to that, financial development also has a positive impact on economic growth. Consequently, these findings confirmed the importance of these determinants in stimulating the economic growth in the selected regions. On the basis of empirical findings, it is suggested that free flow of foreign direct investment benefits the economy. Therefore, policymakers or state should create such desirable environment that attracts direct investment such as well functioned financial markets, etc. According to Alfaro et al. (2004), less developed financial markets and undesirable environment repel foreign direct investment to flow into the country. However, restrictions on foreign direct investment should only impose on the short-term flow, so that economy prevents from distortions. Additionally, the flow of remittances should be encouraged because it reduces poverty and improves the well-being of the society but the flow through illegal channels should be banned or restricted. Furthermore, exports are considered the engine of the economic development, but it sometimes causes problems such depreciate the currency. So policymakers should make certain exports restricted policies that make a balance between imports and exports. Likewise, external assistance in the form of aid or debt resolves the country economic and financial issues, but overwhelming aid creates problems. The extra amount of foreign debt increases the sovereign risk of the country and domestically increases corruption. The state should formulate certain policies that minimize the amount of external debt which can only use for the development purpose. For the future research, more factors of capital flow should include to the study to get more insights about the capital flow and restricted flow impact on the economic growth of specifically selected regions. Moreover, the comparative study could also be conducted on pre and post circumstances of recession using the same variables and time period. More importantly, capital control measures given by IMF is not completely defined the restrictions on fewer factors which changed over the period of time, so alternate measure should be used.

\section{References}

Abdih, Y., Chami, R., Dagher, J., \& Montiel, P. (2012). Remittances and Institutions: Are Remittances a Curse? World Development, 40(4), 657-666.

Abbes, S. M., Mostéfa, B., Seghir, G., \& Zakarya, G. Y. (2015). Causal Interactions between FDI, and Economic Growth: Evidence from Dynamic Panel Co-integration. Procedia Economics and Finance, 23, 276-290.

Adams, R. H., \& Cuecuecha, A. (2013). The Impact of Remittances on Investment and Poverty in Ghana. World Development, 50, 24-40.

https://doi.org/10.1016/j.worlddev.2013.04.009

Ahmed, E. M. (2012). Are the FDI inflow spillover effects on Malaysia's economic growth input driven? Economic Modelling, 29, 1498-1504.

https://doi.org/10.1016/j.econmod.2012.04.010 
Ahmed, S., \& Zlate, A. (2014). Capital flows to emerging market economies: a brave new world? Journal of International Money and Finance, 48, 221-248. https://doi.org/10.1016/j.jimonfin.2014.05.015

Ali, R. \& Mustafa, U. (2012). External debt accumulation and its impact on economic growth in Pakistan. The Pakistan development Review, 51(4), 79-95.

Almfraji, M. A. \& Almsafir, M. K. (2013). Foreign direct investment and economic growth. Literature review from 1994 to 2012. Procedia- Social and Behavioral Science, 129, 206213. https://doi.org/10.1016/j.sbspro.2014.03.668

Ambrosius, C., \& Cuecuecha, A. (2013). Are Remittances a Substitute for Credit? Carrying the Financial Burden of Health Shocks in National and Transnational Households. World Development, 46, 143-152. https://doi.org/10.1016/j.worlddev.2013.01.032

Anzoategui, D., Demirgüç-Kunt, A., \& Martínez Pería, M. S. (2014). Remittances and Financial Inclusion: Evidence from El Salvador. World Development, 54, 338-349. https://doi.org/10.1596/1813-9450-5839

Antwi, S., Mills, E. F. E. A., Mills, G. A. \& Zhao. (2013). Impact of foreign direct investment on economic growth: empirical evidence from Ghana. International Journal of Academic Research in Accounting, Finance \& Management Sciences, 3(1), 18-25.

Asiedu, E., \& Lien, D. (2004). Capital Controls and Foreign Direct Investment. World Development, 32(3), 479-490. https://doi.org/10.1016/j.worlddev.2003.06.016

Awokuse, T. O. (2007). Causality between exports, imports, and economic growth: Evidence from transition economies. Economics Letters, 94(3), 389-395. https://doi.org/10.1016/j.econlet.2006.08.025

Azman-Saini, W. N. W., Baharumshah, A. Z., \& Law, S. H. (2010). Foreign direct investment, economic freedom and economic growth: International evidence. Economic Modelling, 27(5), 1079-1089. https://doi.org/10.1016/j.econlet.2006.08.025

Bakar, N. A. \& Hassan, S. (2008). Empirical evaluation on external debt of Malaysia, International Business \& Economics Research Journal, 7(2), 95-108, DOI:

10.19030/iber.v7i2.3226

Balaguer, J., \& Cantavella-Jordá, M. (2004). Structural change in exports and economic growth: cointegration and causality analysis for Spain (1961-2000). Applied Economics, 36(5), 473-477.doi:10.1080/00036840410001682179

Bhavan, T., Xu, C. \& Zhong, C. (2011). Determinants and Growth Effect of FDI in South Asian Economies: Evidence from a Panel Data Analysis. International Business Research, 4(1), 43-50. Retrieved from www.ccsenet.org/ibr

Catrinescu, N., Leon-Ledesma, M., Piracha, M., \& Quillin, B. (2009). Remittances, Institutions, and Economic Growth. World Development, 37(1), 81-92. https://doi.org/10.1016/j.worlddev.2008.02.004

Chuang, Y. C. (2000). Human capital, exports, and economic growth: a causality analysis for Taiwan, 1952-1995. Review of International Economics, 8, 712-720, https://doi.org/10.1111/1467-9396.00252

Cleeve, E. A., Debrah, Y., \& Yiheyis, Z. (2015). Human Capital and FDI Inflow: An Assessment of the African Case. World Development, 74, 1-14. https://doi.org/10.1016/j.worlddev.2015.04.003

De Arcangelis, G., Joxhe, M., McKenzie, D., Tiongson, E., \& Yang, D. (2015). Directing remittances to education with soft and hard commitments: Evidence from a lab-in-the field experiment and new product take-up among Filipino migrants in Rome. Journal of Economic Behavior \& Organization, 111, 197-208. https://doi.org/10.1016/j.jebo.2014.12.025

De Vita, G., \& Kyaw, K. S. (2008). Determinants of capital flows to developing countries: a 
structural VAR analysis. Journal of Economic Studies, 35(4), 304-322. https://doi.org/10.1108/01443580810895608

Dritsaki, C., \& Stiakakis, E. (2014). Foreign Direct Investments, Exports, and Economic Growth in Croatia: A Time Series Analysis. Procedia Economics and Finance, 14, 181-190. https://doi.org/10.1016/S2212-5671(14)00701-1

Doytch, N., \& Uctum, M. (2011). Does the worldwide shift of FDI from manufacturing to services accelerate economic growth? A GMM estimation study. Journal of International Money and Finance, 30(3), 410-427. https://doi.org/10.1016/j.jimonfin.2011.01.001

Dritsaki, C. (2013). Causal Nexus between Economic Growth, Exports and Government Debt:

The case of Greece. Procedia Economics and Finance, 5, 251-259. https://doi.org/10.1016/S2212-5671(13)00031-2

Elo, K. Z. (2007). The Effect of Capital Controls on Foreign Direct Investment Decisions Under Country Risk with Intangible Assets. Imf Working Paper, 1934-7073.

Fosu, A. K. (2007). Fiscal Allocation for Education in Sub-Saharan Africa: Implications of the External Debt Service Constraint. World Development, 35(4), 702-713. https://doi.org/10.1016/j.worlddev.2006.06.008

Fedderke, J. W., \& Liu, W. (2002). Modelling the determinants of capital flows and capital flight: with an application to South African data from 1960 to 1995. Economic Modelling, 19(3), 419-444. https://doi.org/10.1016/S0264-9993(01)00071-2

Fernández, A., Klein, M. W., Rebucci, A., Schindler, M., \& Uribe, M. (2016). Capital control measures: A new dataset. IMF Economic Review, 64(3), 548-574.

Gokmenoglu, K. K., Sehnaz, Z., \& Taspinar, N. (2015). The Export-Led Growth: A Case Study of Costa Rica. Procedia Economics and Finance, 25, 471-477. doi: 10.1016/S22125671(15)00759-5

Hatemi-J, A., \& Uddin, G. S. (2013). On the causal nexus of remittances and poverty reduction in Bangladesh. Applied Economics, 46(4), 374-382. https://doi.org/10.1080/00036846.2013.844331

Hossain, S., \& Mitra, R. (2013). The Determinants of Economic Growth in Africa: A Dynamic Causality and Panel Cointegration Analysis. Economic Analysis and Policy, 43(2), 217-226.

Iamsiraroj, S., \& Ulubaşoğlu, M. A. (2015). Foreign direct investment and economic growth: A real relationship or wishful thinking? Economic Modelling, 51, 200-213. https://doi.org/10.1016/j.econmod.2015.08.009

Jadhav, P. (2012). Determinants of foreign direct investment in BRICS economies: Analysis of economic, institutional and political factor. Procedia - Social and Behavioral Sciences, 37, 5 - 14. https://doi.org/10.1016/j.sbspro.2012.03.270

Jawaid, S. T. \& Raza, S. A. (2012). Workers' remittances and economic growth in China and Korea: an empirical analysis, Journal of Chinese Economic and Foreign Trade Studies, 5(3), 185 - 193. https://doi.org/10.1108/17544401211263946

Johansson, P. (2010). Debt Relief, Investment and Growth. World Development, 38(9), 12041216. https://doi.org/10.1016/j.worlddev.2009.11.021

Jouini, J. (2015). Economic growth and remittances in Tunisia: Bi-directional causal links. Journal of Policy Modeling, 37(2), 355-373. https://doi.org/10.1016/j.jpolmod.2015.01.015

Karakoy, A. U. C., Kabadayi, B. \& Emsen, O. S. (2012). The impacts of external debt on Economic growth in transition economies, Chinese Business Review, 11(5), 491-499.

Korkmaz, S. (2015). The relationship between external debt and economic growth in Turkey, Proceedings of the Second European Academic Research Conference on Global 
Business, Economics, Finance and Banking (EAR15Swiss Conference), Paper ID: Z581

Kumar, M. S. \& Woo, J. (2010). Public Debt and Growth, IMF Working Papers, 1-74, Available at SSRN: http://ssrn.com/abstract $=1653188$

Kumar, R. R. (2013). Remittances and economic growth: A study of Guyana. Economic Systems, 37(3), 462-472. https://doi.org/10.1016/j.ecosys.2013.01.001

Malik, S., Hayat, M.K. \& Hayat, M.U (2010). External Debt and Economic Growth: Empirical Evidence from Pakistan, International Research Journal of Finance and Economics, (44), 88-97.

Meyer, D., \& Shera, A. (2016). The impact of remittances on economic growth: An econometric model. EconomiA. https://doi.org/10.1016/j.econ.2016.06.001

Medina-Smith, E. J. (2001). Is export-led growth hypotheses valid for developing countries? A case study on Costa Rica. Policy Issues in International Trade and Commodities. Study Series number 7, United Nations Conference on Trade and Development.

Mohd Dauda, S. N., Ahmad, A. H., \& Azman-Saini, W. N. W. (2013). Does External Debt Contribute to Malaysia Economic Growth? Economic Research-Ekonomska Istraživanja, 26(2), 51-68. https://doi.org/10.1080/1331677X.2013.11517606

Mundaca, B. G. (2009). Remittances, financial market development, and economic growth: the case of Latin America and the Caribbean, Review of Developmental Economics, 13(2), 288-303. https://doi.org/10.1111/j.1467-9361.2008.00487.x

Nsiah, C., \& Fayissa, B. (2011). Remittances and economic growth in Africa, Asia, and Latin American-Caribbean countries: a panel unit root and panel cointegration analysis. Journal of Economics and Finance, 37(3), 424-441.

Nyamongo, E. M., Misati, R. N., Kipyegon, L., \& Ndirangu, L. (2012). Remittances, financial development and economic growth in Africa. Journal of Economics and Business, 64(3), 240-260. https://doi.org/10.1016/j.jeconbus.2012.01.001

Omri, A., Nguyen, D. K., \& Rault, C. (2014). Causal interactions between CO2 emissions, FDI, and economic growth: Evidence from dynamic simultaneous-equation models. Economic Modelling, 42, 382-389. https://doi.org/10.1016/j.econmod.2014.07.026

Portugal-Perez, A., \& Wilson, J. S. (2012). Export Performance and Trade Facilitation Reform: Hard and Soft Infrastructure. World Development, 40(7), 1295-1307. https://doi.org/10.1016/j.worlddev.2011.12.002

Qayyum, U., Din, M., \& Haider, A. (2014). Foreign aid, external debt and governance. Economic Modelling, 37, 41-52. https://doi.org/10.1016/j.econmod.2013.08.045

Sbia, R., Shahbaz, M., \& Hamdi, H. (2014). A contribution of foreign direct investment, clean energy, trade openness, carbon emissions and economic growth to energy demand in UAE. Economic Modelling, 36, 191-197. https://doi.org/10.1016/j.econmod.2013.09.047

Schneider, P. H. (2005). International trade, economic growth and intellectual property rights: A panel data study of developed and developing countries. Journal of Development Economics, 78(2), 529-547. https://doi.org/10.1016/j.jdeveco.2004.09.001

Shahbaz, M. \& Mohammad, M. R. (2014). The dynamics of exports, financial development and economic growth in Pakistan: new extensions from cointegration and causality analysis, MPRA, 1-26.

Solow, R. (1956) A contribution to the theory of economic growth. The Quarterly Journal of Economics, 70, 65-94. https://doi.org/10.2307/1884513

Tekin, R. B. (2012). Economic growth, exports and foreign direct investment in Least Developed Countries: A panel Granger causality analysis. Economic Modelling, 29(3), 868-878. https://doi.org/10.1016/j.econmod.2011.10.013

Temiz, D. \& Gokmen, A. (2014). Fdi inflow as an international business operation by mncs and 
economic growth: an empirical study on Turkey. International Business Review, 23(1),145-154. https://doi.org/10.1016/j.ibusrev.2013.03.003

Vohra, R. (2001). Export and economic growth: Further time series evidence from less-develop countries. International Advances in Economic Research, 7(3), 345-350.

Yao, S. (2006). On economic growth, FDI and exports in China. Applied Economics, 38(3), 339 -351. https://doi.org/10.1080/00036840500368730 


\begin{tabular}{|c|c|c|c|}
\hline \multicolumn{4}{|l|}{ Appendices } \\
\hline Country & Income Classification & Country & Income classification \\
\hline Argentina & High Income & Algeria & Upper middle income \\
\hline Australia & High Income & Bangladesh & Lower middle income \\
\hline Chile & High Income & Bolivia & Lower middle income \\
\hline Cyprus & High Income & Brazil & Upper middle income \\
\hline Czech Republic & High Income & Bulgaria & Upper middle income \\
\hline Denmark & High Income & Costa Rica & Upper middle income \\
\hline Guatemala & High Income & Dominican Republic & Upper middle income \\
\hline Hong Kong & High Income & Ecuador & Upper middle income \\
\hline Hungary & High Income & Egypt & Lower middle income \\
\hline Iceland & High Income & El Salvador & Lower middle income \\
\hline Israel & High Income & India & Lower middle income \\
\hline Japan & High Income & Indonesia & Lower middle income \\
\hline Korea & High Income & Kazakhstan & Upper middle income \\
\hline Poland & High Income & Kenya & Lower middle income \\
\hline Singapore & High Income & Kyrgyz Republic & Lower middle income \\
\hline Sweden & High Income & Malaysia & Upper middle income \\
\hline Switzerland & High Income & Mauritius & Upper middle income \\
\hline United Kingdom & High Income & Mexico & Upper middle income \\
\hline United States & High Income & Moldova & Lower middle income \\
\hline Uruguay & High Income & Morocco & Lower middle income \\
\hline & & Nigeria & Lower middle income \\
\hline & & Pakistan & Lower middle income \\
\hline & & Panama & Upper middle income \\
\hline & & Paraguay & Upper middle income \\
\hline & & Peru & Upper middle income \\
\hline & & Philippines & Lower middle income \\
\hline & & Romania & Upper middle income \\
\hline & & South Africa & Upper middle income \\
\hline & & Sri Lanka & Lower middle income \\
\hline & & Thailand & Upper middle income \\
\hline & & Tunisia & Lower middle income \\
\hline & & Turkey & Upper middle income \\
\hline & & Ukraine & Lower middle income \\
\hline & & Venezuela & Upper middle income \\
\hline
\end{tabular}


